\title{
Model Latihan Keterampilan Dibbling Sepak Bola Berbasis Koordinasi Untuk Atlet Sma Kota Mataram
}

\author{
${ }^{1}$ Soemardiawan, ${ }^{2}$ Susi Yundarwati \\ ${ }^{12}$ Fakultas Ilmu Keolahragaan Dan Kesehatan Masyarakat, UNDIKMA \\ ${ }^{1}$ umanksoemardiawan84@gmail.com. ${ }^{2}$ Susiyundarwati@ikipmataram.ac.id
}

\begin{abstract}
The purpose of this research and development is to produce a coordination-based soccer team on soccer for high school students in the city of Mataram. In addition, this research and development is carried out to obtain in-depth information about the development and application of soccer dribbling models, to determine the effectiveness, efficiency and attractiveness of children to the models created. This study uses the Research \& Development $(R \& D)$ development research method from Borg and Gall. The subjects in this research and development were high school students consisting of 60 children. The instruments used in this research and development were questionnaires, questionnaires, as well as a soccer dribbling test instrument which was used to collect data on soccer for high school aged children, while the stages in this research and development were: (1) needs analysis, (2) expert evaluation (initial product evaluation); (3) limited trials (small group trials); and (4) main testing (field testing). The model effectiveness test uses soccer dribbling skills to determine the skill level of dribbling football for high school age before giving treatments in the form of a coordination-based soccer training model developed and to determine the level of dribbling skills after treatment or treatment from the initial tests carried out, the dribbling level is obtained. students were 750, then after being given treatment in the form of a dribbling model, the final test student dribbling skill level was obtained at 940. Then this ball dribbling model is effective in improving learning to dribble soccer for high school age. Based on the data obtained, from the results of field trials and discussion of the results of the study it can be concluded that: with the coordination-based training model for training skills in coordination-based football bling for Mataram city high school athletes, it is effective and efficient, innovative can improve dribbling practice and apply dribbling properly, evidence is obtained. This increase is shown in the results of testing the pretest and posttest results, there is a significant difference between before and after the treatment model.
\end{abstract}

Keywords : Model, dribbling exercise, coordination based, Football

\section{ABSTRAK}

Tujuan dari penelitian dan pengembangan ini adalah untuk menghasilkan dibbling sepak bola berbasis koordinasi pada sepak bola untuk usia SMA di Kota Mataram. Selain itu, penelitian dan pengembangan ini dilakukan untuk memperoleh informasi secara mendalam tentang pengembangan dan penerapan model menggiring sepak bola, mengetahui efektivitas, efisiensi serta daya tarik anak terhadap model yang dibuat. Penelitian ini menggunakan metode penelitian pengembangan Research \& Development (R \& D) dari Borg and Gall. Subyek dalam penelitian dan pengembangan ini adalah siswasiswi SMA yang terdiri dari 60 anak. Instrumen yang digunakan dalam penelitian dan pengembangan ini adalah angket, kuisioner, serta instrumen test menggiring Menggiring sepak bola yang digunakan untuk mengumpulkan data menggiring sepak bola anak usia SMA, adapun tahapan dalam penelitian dan pengembangan ini adalah, pada tahap: (1) analisis kebutuhan, (2) evaluasi ahli (evaluasi produk awal); (3) ujioba terbatas (ujicoba kelompok kecil); dan (4) ujicoba utama (field testing). Uji efektifitas model menggunakan keterampilan menggirirng bola untuk mengetahui tingkat keterampilan menggiring sepak bola untuk usia SMA sebelum pemberian treatmen berupa model latihan dibbling sepak bola berbasis koordinasi yang dikembangkan dan untuk mengetahui tingkat keterampilan menggiring bola setelah 
perlakuan atau treatmen dari tes awal yang dilakukan diperoleh tingkat mengiring bola siswa sebesar 750, kemudian setelah diberikan perlakuan berupa model mengiring bola diperoleh tingkat keterampilan menggiring bola siswa tes akhir sebesar 940. Maka model menggirirng bola ini efektif dalam meningkatkan pembelajaran menggiring sepak bola untuk usia sekolah menengah atas. Berdasarkan data yang diperoleh, dari hasil uji coba lapangan dan pembahasan hasil penelitian dapat disimpulkan bahwa: dengan adanya model latihan keterampilan dibbling sepak bola berbasis koordinasi untuk atlet SMA kota mataram secara efektif dan efisien, inovatif dapat menigkatkan latihan dribbling dan mengaplikasikan menggiring bola dengan baikdiperoleh bukti adanya peningkatan ini di tunjukan pada hasil pengujian data hasil pretes dan posttest adanya perbedaan yang signifikan antara sebelum dan sesudah adanya perlakuan model.

\section{Keywords: Model, Latihan dribbling,berbasisi koordinasi, Sepak bola}

\section{PENDAHULUAN}

Kota Mataram sebagai Icone olahraga kota dan seluruh kabupaten di NTB yang paling sering mengadakan turnamen sepak bola, tingkat SMA untuk pembinan usia remaja dengan banyak nya pemain sepak bola. Latar belakang Dari penelitian ini adalah diman sebanyak $50 \%$ atlet dalam melakukan dribbling kurang dalam kelincahan, kesimbangan. Dilihat dari urgensi masalah diatas $30 \%$ tidak koordinasi, $40 \%$ keterampilan kurang variasi model latihan secara variatif, monoton, terukur, pada saat menggiring bola, Berdasarkan hal tersebut maka diperlukan model latihan agar mampu memperbaiki keterampilan dribbling sepak bola berbasis koordinasi untuk atlet SMA kota mataram, efektif dan efeisien dalam melakukan dribbling sepakbola maka dari itulah perlu dilakukan sebuah penelitian ini.

Permainan sepakbola memiliki bermacam teknik yaitu, shooting (menembak), passing (mengoper), heading (menyundul), control (menguasai), long pass (melambungkan), dan dribbling (menggiring) serta teknik penjaga gawang. Teknik merupakan fundamental yang harus dikuasai oleh semua atlet agar dapat bermain sepakbola dengan terampil yang didasari kemampuan multilateral gerak. Dribbling merupakan kemampuan menggiring bola dari satu tempat ketempat lain dengan tetap menguasai bola yang berguna untuk menghindari hadangan lawan dan untuk mengatur tempo permainan.
Dribbling dipengaruhi oleh beberapa faktor seperti pengalaman bermain yang dimiliki, semakin lama seseorang berlatih tentunya keterampilan juga akan semakin baik. Perkenaan kaki terhadap bola juga menentukan keberhasilan dribbling karena perkenaan kaki yang benar dengan bola akan memudahkan pesepakbola bergerak dengan cepat. Hasil pengamatan dilapangan banyak pemain yang memiliki kurang dalam hal kelincahan, kesimbangan, koordinasi, dan serta kurang variasi model latihan secara efektif, variatif, monoton, terukur, pada saat menggiring bola, dalam mempertahankan bola sangat kurang sehingga pemain tersebut sering terjatuh, begitu juga sebaliknya apabila mempunyai koordinasi yang baik yang bagus tetapi tidak mempunyai kelincahan, keseimbangan maka saat menggiring bola terlihat lambat.

Dengan sumbangan koordinasi menyatakan hubungan harmonis berbagai faktor yang terjadi pada suatu gerakan. Pada dasarnya koordinasi adalah keterpaduan dari beberapa bagian tubuh untuk melakukan sebuah penampilan gerak. Koordinasi merupakan komponen yang penting dalam olahraga dengan berbagai gerakan teknik yang komplek, dalam futsal koordinasi sangat penting pada saat mengumpan dan melakukan tendangan ke gawang. Sama halnya dengan pedapat Bompa yang menyatakan bahwa koordinasi adalah kemampuan gerak dasar kompleka, Bompa , (2009:380). 
Urgensi permaslahan yang didasar keperihatinan akan mandeknya prestasi sepakbola Indonesia pada umumnya di kalangan remaja dan daerah khususnya (Nusa Tenggara Barat) dan keinginan untuk mengembangkan bakat-bakat para pemain di kalangan Remaja yaitu SMA se Kota Mataram akan terjadi degradasi. Subjek dalam penelitian ini atlet Sepak bola berjumlah 24 atlet yang terdiri dari 4 Sekolah SMAN 6 Mataram 5 orang, SMAN 5 Mataram 6 orang, SMAN 3 Mataram 6 orang, SMAN 2 Mataram 6 orang. Se Kota Mataram. kurang variasi model latihan secara efektif, variatif, terukur, monoton pada saat menggiring bola, dalam mempertahankan bola dan diakibatkan kurang koordinasi.

Penelitian model ini adalah solusi untuk meningkatkan keterampilan dribbling sepak bola. Berdasarkan uraian diatas, sebagai rujukan peneliti dalam mengembangkan kemampuan dribbling atlet sepakbola lebih variatif, efektif, tidak monoton, terukur, dan ilmiah berdasarkan sport science untuk memberikan dampak positif terhadap perkembangan sepakbola khsusnya dikalangan remaja SMA Se-kota Mataram, keterampilan dribbling melalui model pengembangan dribbling yang peneliti akan lakukan yang berjudul Model latihan keterampilan dibbling sepak bola berbasis koordinasi untuk atlet SMA kota mataram.

Model menggambarkan tingkat terluas dari praktek pendidikan dan berisikan orientasi filosofis latihan. Model adalah sesuatu yang menggambarkan adanya pola berpikir. Sebuah model biasanya menggambarkan keseluruhan konsep yang saling berkaitan., Benny Pribadi, (2010:100) Sehingga kita bisa berkembang dengan nya model yang akan di kembangkan oleh penelitian akan menunjang kemajuan olahraga yang ada di indonesia dan sebagai bahan perhatian pelatih dan aktivis olahraga yang ada

Dengan pengembangan model latihan keterampilan sepak bola berbasis koordinasi yang menjadi daya tarik dalam penelitian pengembangan model untuk dijadikan materi peneltian yang akan dilaksanakan yaitu pengembangan model latihan yang ada saat ini berupa model latihan yang konvensional dan kurang variasi menjadi model-model latihan bervariasi dan kemudian dikembangkan model latihan dribbling dan dipublikasikan menjadi salah satu alternatif dalam meningkatkan keterampilan prestasi sepak bola khususnya keterampilan dribbling, baik ditingkat klub, regional, nasional, maupun internasionalyang berjudul Model latihan keterampilan dibbling sepak bola berbasis koordinasi untuk atlet SMA kota mataram.

\section{KAJIAN PUSTAKA 1.Model}

Metode penelitian yang relevan dan dapat selalu digunakan yaitu penelitian pengembangan atau Research and Development (R\&D). Winarno, (2011) menjelaskan bahwa "penelitian pengembangan merupakan penelitian yang berupaya mengembangkan produk tertentu sesuai dengan kebutuhan masyarakat saat ini. Penelitian dan pengembangan saat ini banyak digunakan untuk memecahkan masalah pada dunia pendidikan, maka penelitian ini diharapkan mampu membantu seorang guru untuk memecahkan permasalahan. Model adalah sesuatu yang nyata dan dikonversi untuk sebuah bentuk yang lebih komprehensif. Sebagai contoh model pesawat terbang yang terbuat dari kayu, plastik, dan lem adalah model nyata dari pesawat terbang, (Trianto, 2011).

\section{Latihan}

Pengertian latihan yang berasal dari kata training adalah suatau proses peyempurnaan kemampuan keolahragaan yang berisikan materi teori dan praktik menggunakan metode, dan aturan perlaksanaan dengan pendekatan ilmiah memakai prinsip-prinsip latihan yang terencana dan teratur, sehingga tujuan latihan dapat dicapai tepat pada waktunya. Salah satu ciri dari latihan baik yang berasal dari kata practice, exercise, dan training adalah adanya 
beban latihan. Beban latihan merupakan rangsangan motorik gerak yang dapat diatur dan dikontrol oleh pelatih manapun atlet untuk memperbaiki kualitas fungsional berbagai peralatan tubuh, Syafruddin, (2011:23).

\section{Keterampilan}

Keterampilan ini dilakukan dengan rangkaian gerakan yang saling bersenambungan.Widiastuti, (2011). menjelaskan gerak keterampilan adalah: Gerak yang mengikuti pola atau bentuk tertentu yang memerlukan koordinasi dan kontrol sebagian atau seluruh tubuh yang bisa dilakukan melalui proses belajar, Keterampilan dapat dibedakan menjadi empat tingkat penguasaan gerak Widiastuti diantaranya: 1) tingkat pemula (beginner), 2) tingkat madya (intermediate), 3) tingkat lanjut (advance), 4) tingkat mahir (higly skiled). Menggunakan tes keterampilan, kita dapat mengetahui tingkat kemampuan anak didik kita dalam suatu cabang olahraga. Tes keterampilan cabang olahraga, merupakan suatu tes yang akan mengukur keterampilan para siswa dalam suatu cabang olahraga.

\section{Dribbling}

Teknik dasar dribbling adalah keterampilan dasar dalam sepakbola karena semua pemain harus mampu menguasai bola saat sedang bergerak, berdiri, atau bersiap melakukan operan atau tembakan. Ketika pemain telah menguasai kemampuan dribbling secara efektif, sumbangan mereka di dalam pertandingan akan sangat besar (Dewi \& Darmawan, 2017:160). Dribbling adalah keterampilan dasar dalam sepak bola karena semua permainan harus mampu mengatasi bola saat sedang bergerak, berdiri atau bersiap melakukan operan atau tembakan. Ketika pemain telah menguasai kemampuan dribbling secara efektif, sumbangan mereka di dalam pertandingan akan sangat besar

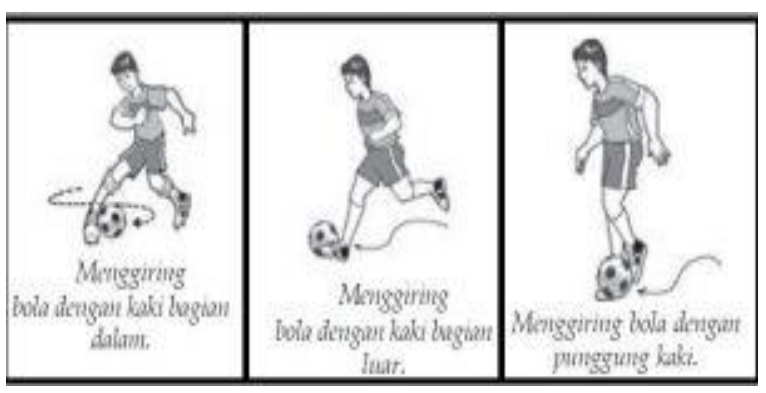

Gambar 1.1 Retrieved From:

https://olahragapedia.com/teknik-dasarpermainan-sepak-bola

Kunci untuk sukses seseorang saat dribbling bola agar bola tetap terkontrol ada tiga fase yaitu:

(1)Fase persiapan: lutut ditekuk, posisi berjongkok, titik berat badan rendah, badan diatas bola, kepala tegak jika mungkin.

(2)Fase pelaksanan: fokus ke bola, gunakan gerak tipu badan, dan tipuan gerak kaki, kontrol bola dengan permukaan kaki yang cocok, rubah kecepatan arah atau kedua-duanya.

(3)Fase Lanjutan: pertahankan kontrol yang rapat, tambah kecepatan menjauhi lawan, pandangan luas dan lihat lapangan.

\section{Koordinasi}

Widiastuti, (2011:17) Koordinasi menurut widiastuti merupakan kemampuan untuk melakukan gerakan atau kerja dengan tepat dan efesien. koordinasi menyatakan hubungan harmonis berbagai faktor yang terjadi pada suatu gerakan. Pada dasarnya koordinasi adalah keterpaduan dari beberapa bagian tubuh untuk melakukan sebuah penampilan gerak. Koordinasi merupakan komponen yang penting dalam olahraga dengan berbagai gerakan teknik yang komplek, dalam sepak bola. Tingkat kemampuan koordinasi mencerminkan kemampuan untuk melakukan gerakan dengan berbagai tingkat kesulitan dan kecepatan, dengan sangat teliti dan efisien, dan sesusai dengan tujuan khusus latihan.

\section{Sepak bola}

Permainan sepak bola merupakan salah satu cabang olahraga yang dimainkan oleh 11 orang dalam setiap tim. Hidayat, (2017:5) sepak bola merupakan salah satu cabang olahraga yang di mainkan di luar ruangan. 
Olahraga ini di mainkan di atas sebuah kawasan yang lapang oleh dua kelompok yang di sebut tim. Setiap tim memiliki gawang Pada bagian tengah masing-masing ujung lapangan. Bentuk gawang ini adalah empat persegi panjang yang memiliki ukuran 7,32 meter serta berketinggian 2,44 meter Mereka saling berhadapan dengan tujuan untuk memasukan bola kedalam gawang masing-masing lawan.Untuk bermain sepak bola, di lakukan di atas lapangan ukuran 100-120 meter. Sementara untuk lebar lapangan memiliki 6575 meter.

\section{METODE PENELITIAN}

\section{Rancangan kegiatan}

Dalam Penelitian pengembangan ini menggunakan model pengembangan Research \& Development (R \& D) dari Borg dan Gall yang terdiri dari sepuluh langkah beserta tahapan penelitian antara lain sebagi berikut: (1) Melakukan penelitian dan pengumpulan informasi (kajian pustaka, pengamatan subyek, persiapan laporan pokok persoalan) (2) Melakukan perencanaan (pendefinisian keterampilan, perumusan tujuan, penentuan urutan pengajaran, dan uji coba skala kecil) (3) Mengembangkan bentuk produk awal (penyiapan materi pengajaran, penyusunan buku pegangan, dan perlengkapan evaluasi) (4) Melakukan uji lapangan permulaan (menggunakan 6-12 subyek) (5) Melakukan revisi terhadap produk utama (sesuai dengan saran-saran dari hasil uji lapangan permulaan) (6) Melakukan uji lapangan utama (dengan 30-100 subyek. (7) Melakukan revisi produk (berdasarkan saran-saran dan hasil uji coba lapangan utama). (8) Uji lapangan dengan 40-200 subyek (9) Revisi produk akhir (10) Membuat laporan mengenai produk pada jurnal, bekerja dengan penerbit yang dapat melakukan distribusi secara komersial. Peneliti mendapatkan hasil data keterampilan melalui penilaian instrumen menggring bola (dribble) pada permainan sepakbola yaitu melalui tes menggiring bola (dribbling):

Tahapan Penelitian yang diadopsi dalam penelitian pengembangan model latihan dribbling dengan permainan cabang olahraga sepak bolaini adalah merujuk pada langkahlangkah yang diajukan oleh Borg \& Gall (2005:509) seperti terlihat pada gambar berikut ini:

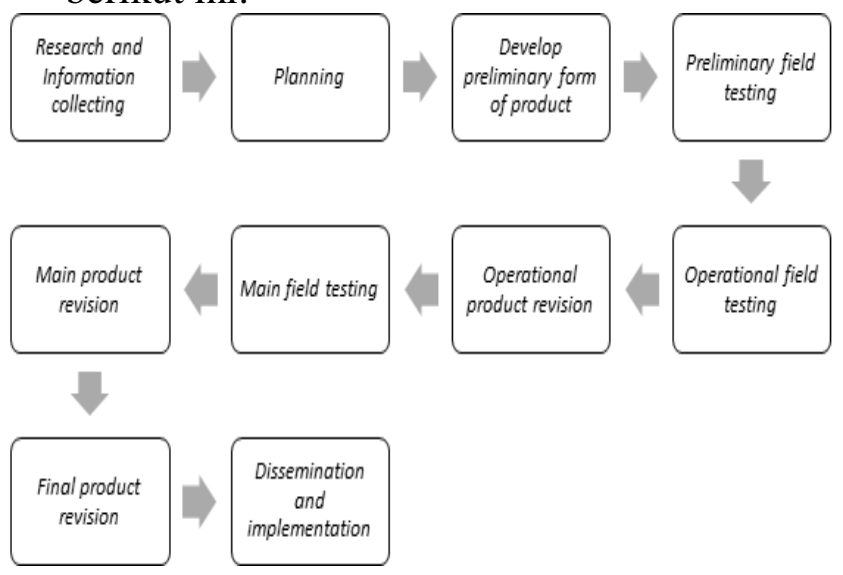

Gambar 1.2. Langkah-Langkah Penelitian dan Pengembangan Menurut Borg dan Gall.

\section{Ruang lingkup}

Pendekatan yang dipergunakan dalam penelitian ini adalah pendekatan kualitatif dan kuantitatif, diman Model latihan keterampilan dibbling sepak bola berbasis koordinasi untuk atlet SMA Kota Mataram. Penelitian ini dilaksanakan di 3 sekolah yang berbeda yaitu : SMAN 6 Mataram 20 orang, SMAN 5 Mataram 20 orang, SMAN 3 Mataram 20 orang. Adapun sasaran dalam penelitian yang peneliti lakukan ini adalah diperuntukkan untuk anak Remaja (SMA) dan dewasa berjumlah 60 orang sampel, teknik pengambilan sampel menggunakan purposive sampling. Waktu dalam penelitian riset dan pengembangan model ini di mulai dari Maret sampai dengan Desember 2020 dengan mengacu pada penelitian riset dan pengembangan model. Penelitian model ini menggunakan pendekatan kualitatif dan kuantitatif serta menggunakan model 
pengembangan Research \& Development $(R$ $\& D)$ dari Borg dan Gall yang terdiri dari sepuluh langkah atau dapat juga digambarkan dalam bentuk skema tahapan pengembangan seperti pada gambar dibawah ini

\section{Bahan dan alat utama}

Peneliti mendapatkan hasil data keterampilan melalui penilaian instrumen menggring bola (dribble) pada permainan sepakbola yaitu melalui tes menggiring bola (dribbling):

a. Tujuan:

Mengukur keterampilan, kelincahan, dan kecepatan kaki dalam memainkan bola.

b. Alat yang digunakan:

1. Bola

2. Stopwatch

3. 6 buah rintangan (tongkat/lembing)

4. Tiang bendera

5. kapur

c. Pelaksanaan pelaksanaan tes:

1. Pada aba-aba "Siap" testee berdiri dibelakang garis star dengan bola dalam penguasaan kakinya

2. Pada aba-aba "Ya", testee mulai menggiring bola ke arah kiri melewati rintangan pertama dan berikutnya menuju rintangan berikutnya sesuai dengan arah panah yang telah ditetapkan sampai testee melewati garis finish

3. Salah arah dalam menggiring bola, testee harus memperbaiki tanpa menggunakan anggota badan selain kaki dimana melakukan kesalahan dan selama itu pula stopwatch tetap jalan

4. Menggiring bola dilakukan dengan kaki kanan dan kiri secara bergantian, atau minimal salah satu kaki pernah menyentuh bola satu kali sentuhan.

Gerakan tersebut dinyatakan gagal bila:

1. Testee menggiring bola hanya dengan menggunakan satu kaki saja

2. Testee menggiring bola tidak sesuai dengan arah panah.
3. Testee menggunakan anggota badan selain kaki pada saat menggiring bola.

\section{d. Cara menskor:}

Waktu yang ditemuh oleh testee dari aba-aba "Ya" sampai testee melewati garis finish.

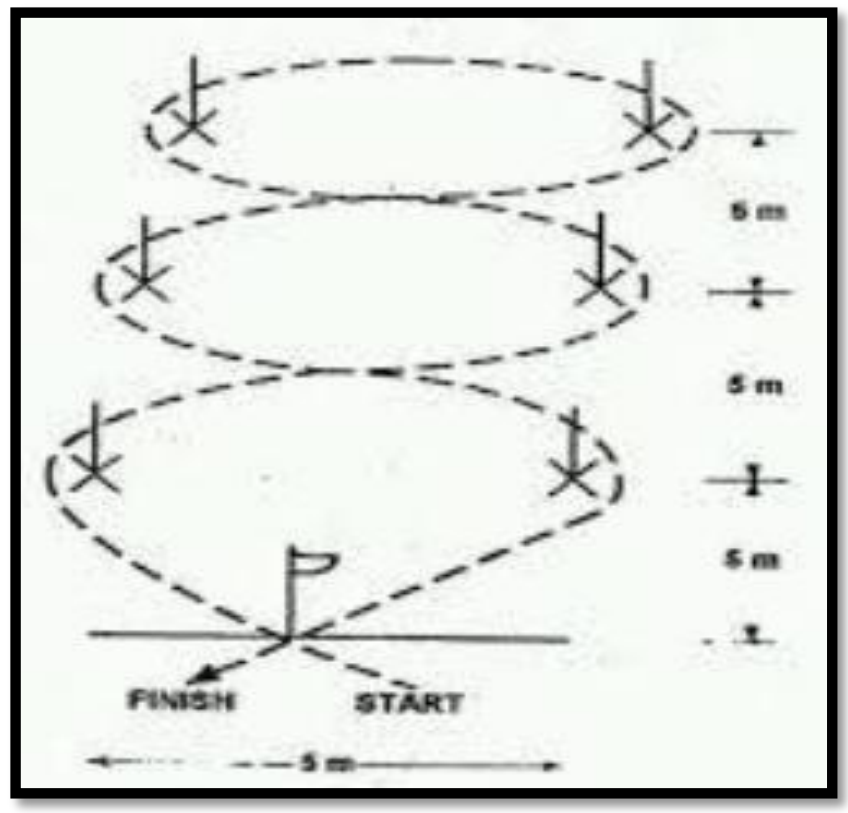

Gambar 1.3 Denah Lapangan Tes Keterampilan Menggiring Sumber: (Nurhasan, 2000:153)

\section{Tempat}

Penelitian ini dilaksanakan di 4 sekolah yang berbeda yaitu : SMAN 6 Mataram 5 orang, SMAN 5 Mataram 6 orang, SMAN 3 Mataram 6 orang, SMAN 2 Mataram 6 orang. Adapun sasaran dalam penelitian yang peneliti lakukan ini adalah diperuntukkan untuk anak Remaja (SMA) dan dewasa berjumlah 24 orang sampel, teknik pengambilan sampel menggunakan purposive sampling. Waktu dalam penelitian riset dan pengembangan model ini di mulai dari Maret sampai dengan Desember 2020 dengan mengacu pada penelitian riset dan pengembangan model

\section{Teknik penumpulan data}

yang digunakan dalam pengembangan penelitian adalah data kuantitatif dan kualitatif. Data kualitatif digunakan utuk melengkapi tujuan pertama, seperti Angket, 
kusioner, observasi lapangan dan dukumentasi sedangkan data kuantitatif digunakan untuk mengungkap tujuan kedua, dengan rancangan penelitian pra-eksperimen tentang model latihan keterampilan dibbling sepak bola berbasis koordinasi untuk atlet SMA kota mataram.

\section{Difinisi operasional variable}

\section{a) Model}

Bompa dalam Roesdiyanto dan Budiwanto menyatakan bahwa model adalah suatu tiruan, suatu tiruan dari aslinya, mengatur bagian khusus suatu fenomena yang diamati atau diselidiki. Hal itu juga merupakan suatu jenis bayangan isomorphosa (sama dengan bentuk pertandingan), yang diamati melalui abstraksi, suatu proses mental membuat generalisasi dari contoh konkrit. Selama menciptakan suatu model, mengatur hipotesis adalah sangat penting untuk perubahan dan menghasilkan analisis, (Roesdiyanto dan Setyo Budiwanto, (2010:34).

b) Latihan

Dari beberapa istilah tersebut, setelah diaplikasikan di lapangan memang nampak sama kegiatannya, yaitu aktivitas fisik. Salah satu ciri dari latihan yang baik yang berasal dari kata practice, exercise, dan training adalah adanya beban latihan yang mana merupakan rangsang mototrik (gerak) yang dapat diatur dan dikontrol oleh pelatih maupun atlet untuk memperbaiki kualitas fungsional berbagai peralatan tubuh Mylsidayu dan Kurniawan, (2015:47).

\section{c) Keterampilan}

Keterampilan manusia meliputi beberapa bentuk, ada yang menekankan pada kontrol dan koordinasi kelompok otot-otot besar, secara relatif menunjukkan kekuatannya seperti sepakbola atau berguling, ada yang sekelompok otot kecil yang harus tepat bekerja seperti mengetik dan memperbaiki jam.

\section{d) Dribbling}

Robert Koger (2007:51)

menyatakan bahwa: Menggiring bola adalah metode menggerakkan bola dari satu titik ke titik lain di lapangan dengan menggunakan kaki, bola harus selalu dekat dengan kaki agar mudah dikontrol

e) Koordinasi

Tangkudung, (2012:68) koordinasi adalah kemampuan gerakan dengan berbagi tingkat keseukran dengan cepat dan efisiendan penuh ketepatan.

\section{f) Sepak bola}

Luxbacher, (2012:21) sepak bola merupakan salah satu cabang olahraga yang di mainkan di luar ruangan. Olahraga ini di mainkan di atas sebuah kawasan yang lapang oleh dua kelompok yang di sebut tim. Setiap tim memiliki gawang pada bagian tengah masing-masing ujung lapangan. Bentuk gawang ini adalah empat persegi panjang yang memiliki ukuran 7,32 meter serta berketinggian 2,44 meter Mereka saling berhadapan dengan tujuan untuk memasukan bola kedalam gawang masing-masing lawan. Untuk bermain sepak bola, di lakukan di atas lapangan ukuran 100-120 meter. Sementara untuk lebar lapangan memiliki 65-75 meter

\section{Teknik analisa data}

Teknik Analisa Data digunakan adalah Uji Hipotesis $U j i-t$ adalah teknik statistik yang digunakan untuk menguji signifikansi perbedaan dua buah mean yang berasal dari dua buah distribusi. Uji hipotesis dilakukan uji-t dua smapel yang berkorelasi, menggunakan bantuan hipotesis SPSS 22 For Windows Evaluations Version. Kriteria pengembangan keputusan jika $\mathrm{t}$ hitung $>\mathrm{t}$ Tabel dan $\mathrm{P}<0,05$ Maka H0 ditolak dan Ha dierima. Jenis penelitian ini eksperimen pendekatan kuantitatif dan kualitatif .

Teknik analisis yang digunakan dalam penelitian model latihan keterampilan dibbling sepak bola berbasis koordinasi untuk 
atlet SMA kota mataram. adalah teknik analisis deskriptif persentase yang digunakan untuk menganalisis hasil dari analisis kebutuhan, evaluasi ahli, dan uji coba Melakukan uji lapangan utama, dengan rancangan penelitian pra-eksperimen berbentuk the one group pretest-postest design, (Maksum.2012:792).

\begin{tabular}{cccc}
\hline Subyek & Pre-test & Perlakuan & $\begin{array}{c}\text { Post- } \\
\text { test }\end{array}$ \\
\hline $\mathrm{R}$ & $\mathrm{O}_{1}$ & $\mathrm{P}$ & $\mathrm{O}_{2}$ \\
\hline
\end{tabular}

Tabel 1.1. Desain Penelitian dalam Uji Efektifitas Model

Dalam uji coba ini, langkah-langkah yang dilakukan adalah sebagai berikut: (1) menetapkan kelompok subyek penelitian; (2) melaksanakan pre-test Keterampilan dribbling sepak bola $\left(\mathrm{O}_{1}\right)$; (3) mencobakan model latihan keterampilan dibbling sepak bola berbasis koordinasi (P); (4) melaksanakan post-test Keterampilan dribbling sepak bola $\left(\mathrm{O}_{2}\right)$; (5) mencari skor rata-rata hasil pre-test dan post-test, lalu membandingkan keduanya; (6) mencari selisih perbedaan kedua rata-rata tersebut melalui metode statistik (uji-t) untuk mengetahui apakah terdapat pengaruh yang signifikan dari penggunaan model pelatihan tersebut. Data-data lain dalam bentuk catatan lapangan dan dokumentasi harus ada dalam uji coba utama sehingga ada umpan balik (feedback) yang dapat digunakan untuk perbaikan dan penyempurnaan model pembelajaran dalam pengembangan berikutnya sampai pada optimalisasi yang merupakan bentuk akhir yang siap dipakai.

\section{HASIL DAN PEMBAHASA}

Bahwa ada 10 dari 20 bentuk model dibbling sepak bola berbasis koordinasi yang telah dikembangkan, Berdasarkan uji ahli yang dilakukan tentang model latihan dribbling bola dalam sepak bola untuk usia SMAN di Kota Mataram Tahun 2020, dapat ditarik kesimpulan sebagai berikut: (1) Berdasarkan uji ahli yang dilakukan dapat disimpulkan bahwa variasi model 10 dan 20 merupakan model latihan dribbling yang tidak layak diberikan pada siswa SMAN. (2) Untuk variasi model pembelajaran 20 dilihat memiliki tingkat kesulitan yang sedang sehingga dapat memudahkan siswa dalam melakukan gerakan, akan tetapi untuk dapat lebih meyakinkan lagi variasi ini akan dilihat efektifitas dan kelayakannya setelah ujicoba kelompok kecil. (3) Berdasarkan uji ahli yang dilakukan dari 20 variasi model latihan dribbling menyisakan 10 variasi model saja yang akan di ujicobakan pada tahap selanjutnya. (4) Petunjuk pelaksanaan harus dibuat secara jelas supaya mudah untuk dipahami.

\section{Efektifitas Model}

\section{Hasil Tahap Pertama/Ujicoba Kelompok Kecil}

Tahap uji coba kelompok kecil pada siswa SMA Mataram yang berjumlah 15 orang diambil dari 3 sekolahan SMA Kota Mataram model latihan keterampilan dibbling sepak bola berbasis koordinasi untuk atlet SMA kota mataram, yang peneliti buat setelah dievaluasi ahli, kemudian mengalami revisi tahap I. Data yang diperoleh digunakan sebagai landasan dalam melakukan revisi pada tahap pertama selanjutnya yaitu ujicoba tahap II. Berdasarkan evaluasi ujicoba kelompok kecil yang dilakukan oleh peneliti dapat disimpulkan sebagai berikut: (1) Pada dasarnya semua variasi dapat diterapkan, akan tetapi harus disesuaikan dari tingkatan yang mudah ke yang sulit agar kemampuan anak dapat meningkat. (2) Pada saat melakukan uji coba kelompok kecil bahwa dari semua model harus diurut dari model latihan dribbling bola yang mudah ke tingkat yang lebih sulit.

2. Hasil Tahap Kedua/Ujicoba Kelompok Besar

Setelah hasil pengembangan produk model latihan keterampilan dibbling sepak bola berbasis koordinasi untuk atlet SMA 
kota mataram, diujicobakan dalam jumlah kecil dan telah direvisi, maka tahap selanjutnya adalah melakukan ujicoba kelompok besar. Berdasarkan hasil uji coba

\begin{tabular}{|c|c|c|c|c|c|c|c|c|}
\hline & \multicolumn{5}{|c|}{ Paired Differences } & & & \multirow{3}{*}{$\begin{array}{l}\text { Sig. } \\
(2- \\
\text { tailed })\end{array}$} \\
\hline & \multirow[t]{2}{*}{ Mean } & \multirow[t]{2}{*}{$\begin{array}{l}\text { Std. } \\
\text { Deviation }\end{array}$} & \multirow[t]{2}{*}{$\begin{array}{l}\text { Std. Error } \\
\text { Mean }\end{array}$} & $\begin{array}{l}95 \% \\
\text { Interval } \\
\text { Differe }\end{array}$ & $\begin{array}{l}\text { Confidence } \\
\text { of the }\end{array}$ & & $\mathrm{Df}$ & \\
\hline & & & & Lower & Upper & & & \\
\hline $\begin{array}{l}\text { Tes awal } \\
\text { Tes Akhir }\end{array}$ & -3.167 & 1.824 & .236 & -3.638 & -2.695 & -13.446 & 59 & .000 \\
\hline
\end{tabular}

terbatas (ujicoba kelompok kecil) yang telah dievaluasi oleh para ahli, kemudian peneliti melakukan revisi produk awal dan memperoleh 20 model latihan dribbling bola berbasis permainan yang akan digunakan dalam ujicoba kelompok besar. Langkah selanjutnya setelah model mengalami revisi tahap II dari ahli maka dilanjutkan dengan menguji cobakan produk kepada kelompok besar dengan menggunakan subyek penelitian sebanyak 60 orang yang terdiri dari 20 Siswa SMA 6 Mataram, 20 Siswa SMA 5 mataram dan 20 Siswa SMA 3 Mataram.

Data pada tabel di atas adalah hasil Pre Test dan hasil Post Test yang diperoleh uji coba kelompok besar yang sebelumnya dilakukan Pre Test atau tes awal dan Post Test yang dilakukan pada siswa, sebelum penerapan model latihan dribbling yang di terapkan kepada siswa. Peneliti melakukan tes awal untuk mengetahui hasil dribbling bola dalam sepak bola untuk usia SMA di Kota Mataram Tahun 2020, yang dimiliki oleh subjek yang akan diteliti, setelah treatmen diberikan maka subjek di tes lagi dengan tes yang sama dengan pre-tes menggiring bola, sebelumnya tes ini dinamakan post test yang digunakan untuk mengetahui apakah terdapat peningkatan hasil model latihan keterampilan dibbling sepak bola berbasis koordinasi untuk atlet SMA kota mataram setelah pemberian treatmen berupa model latihan dibbling.
Untuk menghitung uji efektifitas menggunakan (uji t) dengan analisis perbedaan dua rerata untuk sampel tak bebas seperti pendapat pada Kadir (2010: 198) tentang sampel tak bebas adalah sampel yang keberadaannya saling mempengaruhi (berkorelasi). Dalam perhitungan menggunakan SPSS 16 dengan analisis paired sample $t$-test.

\section{Nilai Rata-rata}

Tabel 1.2. Nilai Rata-rata

Berdasarkan hasil output dengan menggunakan SPSS 16 bahwa nilai rata-rata hasil latihan dibbling sebelum diberikan model latihan keterampilan dibbling sepak bola berbasis koordinasi untuk atlet SMA kota mataram adalah 12.50 dan setelah diberikan perlakuan dengan model 15.67 artinya bahwa nilai rata-rata dribling sepak bola adanya peningkatan.

\section{Koefisien Korelasi}

\section{Tabel 1.3. Koefisien Korelasi} Correlations

\begin{tabular}{|ll|l|l|}
\hline & & Awal & Akhir \\
\hline T. Awal & Pearson Correlation & 1 & $.910^{* *}$ \\
& Sig. (2-tailed) & & .000 \\
& $\mathrm{~N}$ & 60 & 60 \\
\hline T. Akhir & Pearson Correlation & $.910^{* *}$ & 1 \\
& Sig. (2-tailed) & .000 & \\
& $\mathrm{~N}$ & 60 & 60 \\
\hline
\end{tabular}

Berdasarkan hasil ouput tabel di atas bahwa koefisien korelasi latihan dribbling sebelum dan sesudah diberikan model dribbling adalah p-value $0.00<0.05$ jadi kesimpulannya singnifikan.

\section{Signifikansi Perbedaan}

Paired Samples Statistics

\begin{tabular}{|ll|l|l|l|l|}
\hline & & Mean & $\mathbf{N}$ & $\begin{array}{l}\text { Std. } \\
\text { Deviati } \\
\text { on }\end{array}$ & $\begin{array}{l}\text { Std. Error } \\
\text { Mean }\end{array}$ \\
\hline Pair & Tes Awal & 12.50 & 60 & 4.339 & .560 \\
1 & Tes Akhir & 15.67 & 60 & 4.237 & .547 \\
\hline
\end{tabular}




\section{Tabel 1.4 Paired Sampel TI Tes Signifikansi Perbedaan}

Dalam uji signifikansi perbedaan dengan SPSS 16 didapat hasil t-hitung $=13.446, \mathrm{df}=59$ dan p-value $=0.00<0.05$ yang berarti terdapat perbedaan yang signifikan latihan dibbling siswa sebelum dan sesudah adanya perlakuan model latihan keterampilan dibbling sepak bola berbasis koordinasi untuk atlet SMA kota mataram. Berdasarkan keterangan tersebut dapat dikatakan bahwa model latihan dibbling bola sepak bola untuk usia sekolah menengah atas yang dikembangakan, efektif dapat meningkatkan latihan dribbling bola dalam sepak bola untuk usia SMA di Kota Mataram. Berikut perbandingan rata-rata dari tingkat keterampilan mengiring bola sebelum pemberian treatmen dan sesudah pemberian perlakuan dengan latihan dibbling spak bola dengan diagram batang pada gambar berikut ini:
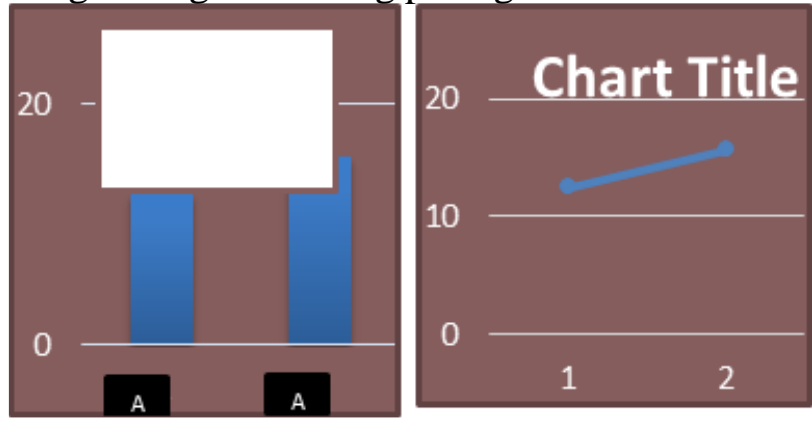

Gambar 1. 4 Diagram Batang

(Uji Coba Kelayakan Produk)

Hasil ujicoba kelompok kecil dan ujicoba kelompok besar dapat disimpulkan bahwa latihan dibbling bola dalam sepak bola untuk usia SMA di Kota Mataram. dapat digunakan dalam proses latihan dibbling sepak bola SMA serta layak dan efektif untuk meningkatkan model latihan keterampilan dibbling sepak bola berbasis koordinasi untuk atlet SMA.

\section{Pembahasan}

Berdasarkan perolehan angka pada tabel di atas dapat disimpulkan bahwa model latihan dibbling bola dalam sepak bola untuk usia SMA di Kota Mataram. dapat dan layak untuk digunakan dalam latihan dibbling di sekolah serta efektif untuk meningkatkan kemampuan dibbling sepak bola. Terdapat perbandingan angka yang menunjukan hasil dari tes awal dan tes akhir mengalami perkembangan, dari tes awal yang berjumlah 750 kemudian diberikan perlakukan latihan dibbling bola yang sudah dikembangkan kemudian baru diadakan tes akhir atau post test untuk mengetahui efektivitas model yang dikembangkan dan diperoleh data berjumlah 940 jadi latihan dibbling menggirirng bola efektif untuk pengembangan model latihan keterampilan dibbling sepak bola berbasis koordinasi untuk atlet SMA. Melihat kekurangan dan kelebihan dari produk yang dibuat terdapat masukan yang akan peneliti sampaikan demi tercapainya penyempurnaan produk ini, adapun masukannya adalah sebagai berikut:

a. Dalam model ini perlu adanya penyesuaian gerakan terhadap siswa yang belajar dengan latihan dibbling berbasis koordinasi sepak bola secara secara efektif, variatif, inovatif.

b. Penggunaan peralatan yang lebih banyak dan memperhatikan kenyamanan serta keamanan dapat membuat anak lebih maksimal dalam melakukan latihan dibbling berbasis koordinasi sepak bola yang di berikan.

c. Karakteristik dan pemahaman siswa, mengharuskan guru memberikan praktik langsung kepada siswa untuk mempelajari latihan dibbling berbasis koordinasi sepak bola.

\section{KESIMPULAN}

Dari hasil penelitian di atas bahwa model latihan model latihan keterampilan dibbling sepak bola berbasis koordinasi untuk atlet SMA kota mataram secara efektif dan efisien, inovatif sesuai dengan materi latihan dribbling yang dibuat oleh peneliti sebelumnya hanya melihat dari aspek teknik dasar saja, namun banyak sekali faktor dilihat dari gerak motorik, dengan 
pola gerak motorik atlit tersebut, dapat meningkatkan dribbling sepak bola berbasisi koordinasi dilihatdari segi gerak motorik, sikap badan, paha, pergelangan kaki, pada perkenaan sepak bola pada saat dribbling.

\section{SARAN}

Berdasarkan data yang diperoleh, dari hasil uji coba lapangan dan pembahasan hasil penelitian dapat disimpulkan bahwa: dengan adanya model latihan keterampilan dibbling sepak bola berbasis koordinasi untuk atlet SMA kota mataram secara efektif dan efisien, inovatif dapat menigkatkan latihan dribbling dan mengaplikasikan menggiring bola dengan baik.

\section{DAFTAR PUSTAKA}

Benny Pribadi. 2009. Model Desain Sisitem Pembelajaran. Jakarta:Dian Aksara.

Bompa, Tutor O. 2009. Theory and Methodology of Training, IWOA: Kendal/Hunt Publishing Company,

Borg, W.R. \& Gall, M.D,.1983. Educational Research An Introduction. Longman: New York.

Borg, W,R \& Gall, M.D,. Gall. 2005. Educational Research: An Intriduction, Eight Editi : New York: Longman.

Creswell, John W. 2010. Research Design Pendekatan kuantitatif, kualitatif dan Mixed. Yogyakarta: Pustaka Pelajar

Dewi, S. K. \& Darmawan, G. (2017) Peningkatan Hasil Belajar Dribbling Sepakbola Melalui Modifikasi Pembelajaran Small Side Games (Pada Siswa Kelas XI SMA Negeri I Bojonegoro). Jurnal Pendidikan Olahraga dan Kesehatan Volume 05 Nomor 02 Tahun 2017, 158 - 163.

Hidayat Witono. 2017. Buku Pintar Sepak Bola. Jakarta Timur : Anugrah.

Luxbacher, Joseph A.2012. SEPAKBOLA: Langkah-langkah Menuju Sukses (Soccer:Steps to Success). Alih Bahasa.
Agusta Wibawa (ed.2) Jakarta: PT.RajaGravindoPersada

Maksum, Ali. 2012. Metodologi Peneleitian Dalam Olahraga. Surabaya : Unesa University Press.

Nurhasan 2000. Tes Dan Pengukuran Pendidikan Olahraga. Fakultas Pendidikan Olahraga dan Kesehatan, Universitas Pendidikan Indonesia.

Mylsidayu Apta dan Kurniawan .2015. Febi. Ilmu Kepelatihan Dasar. Bandung: Alfabeta.

Roesdiyanto \& Setyo Bidiwanto 2010. DasarDasar Kepelatihan Olahraga. Malang: Laboratorium Ilmu Keolahragaa Universitas Negeri Malang.

Syafruddin.2011. Ilmu Keepelatihan Olahraga .

Teori dan Aplikasinya Dalam Pembinaan Olahraga.

Tangkudung, J. 2012. Kepelatihan Olahraga, Pembinaan Prestasi Olahraga Edisi II. Jakarta: Cerdas Jaya.

Widiastuti, 2011. Tes dan Pengukuran Olahraga. Jakarta: PT. Bumi Timur Jaya.

Winarno. 2011. Metodologi Penelitian Dalam Pendidikan Jasmani. Malang: Media Cakrawala Utama Press.

Trianto. 2011. Mendesain Model Pembelajaran tnovatif Progresif Jakarta : Kencana 